\title{
The role of European funds in developing and sustaining rural entrepreneurship in Romania
}

\author{
Florina RĂZVANȚĂ (PUIE) \\ Bucharest University of Economic Studies, Bucharest, Romania \\ florinapuie@gmail.com
}

\begin{abstract}
With the integration into the European Union (EU) in 2007, growth opportunities have arisen for Romania. In terms of rural area and agriculture, National Rural Development Programs (NRDPs) are implemented, through which funds are granted from the European Union and the Government of Romania, for the economic and social development of the rural area. In this context, entrepreneurial initiatives for rural development have been encouraged, and many SMEs were given the opportunity to be eligible for European funding. The NRDP 2014-2020 continues the efforts for rural development, through strategic objectives, allowing entrepreneurs to implement their business ideas and sustain the development of the rural communities. The paper aims to analyze how the European funding influences the development of rural entrepreneurship in Romania. The study will comprise an analysis of the existing results of the NRDP 2014-2020, referring to annual evaluation indicators of the project implementation (number of jobs created in supported projects, percentage of rural population targeted by local development strategies, etc.). The methodology focuses on interpretation of the latest statistical data from trusted sources, as well as analysis of the official documents and reports (e.g. NRDP 2014-2020 annual report). This paper will contribute with accurate results and discussions concerning the role of EU funds for the rural communities. Also, the study will describe some of the challenges that Romanian rural entrepreneurship still faces after implementation of European funding programs and unresolved issues.
\end{abstract}

Keywords: European funding, NRDP, beneficiaries, rural entrepreneurship, rural development.

\section{Introduction}

The European Union (EU) was created around the purpose to be an international organization of independent member states, sharing common institutions, establishing a common market, coordinating social policy and developing a progressive harmonization of national economies. Criteria for accession to the European Union were focusing on respecting general principles such as liberty, democracy, respect for human rights and fundamental freedoms, as well as the rule of law. However, as the European Union regulations stipulate, there is a complex procedure for a nation to become a member state. After meeting the criteria for membership, the applicant country must implement EU rules and regulations in all areas (European Union, Countries, 2020).

Accession of Romania to the European Union membership has raised high expectations for the country even before joining the EU, at the institutional, economical, and political level. These expectations have "forced" Romania to overcome its condition and propose new strategies for development. Nevertheless, Romania was facing the struggle to go through all the existing challenges keeping it from development, in order to reach an upcoming growth opportunity. The imposed EU rules and regulations kept the country on a straight line to follow, and still after accession, it has to comply with them, in all areas stipulated by the EU Law (Istudor, 2006).

With the integration into the European Union in 2007, Romania follows, in terms of agriculture and rural development, the principles of the Common Agricultural Policy (CAP). This policy works as a common policy for all $28 \mathrm{EU}$ countries, and foresees to strengthen the competitiveness and sustainability of EU agriculture. With the aim to respond to members states' specific needs, the CAP provides direct payments for stabilizing farm revenues, and sustains the 
development national and regional rural development programs. In this manner, through the common agricultural policy, the European Union sustains the development of the rural economy, and life in rural areas (European Commission, Common agricultural policy, 2013).

According to Council Regulation (EC) no. 1290/2005 on the financing of the common agricultural policy, two European agricultural funds were created, namely the European Agricultural Guarantee Fund (EAGF), for the financing of market measures, and the European Agricultural Fund for Rural Development (EAFRD), for the financing of rural development programs (European Council, 2005).

Starting from the Council Regulation (EC) no. 1698/2005, from September 20, 2005, on support for rural development through the European Agricultural Fund for Rural Development (EAFRD), a National Strategic Plan for Romania was created, which is the basis for the implementation of the National Program for Rural Development for the period 2007 - 2013 (European Council, 2005).

In this context, Romania is granted with funds from the European Union, through the implementation of the National Rural Development Program (NRDP), for the economic and social development of the rural areas. The first program, implemented in the 2007-2013 period, had four priority directions for financing: (1) Increasing the competitiveness of the agricultural and forestry sector; (2) Improvement of the environment and rural areas; (3) Improving the quality of life in rural areas and diversifying the rural economy; (4) LEADER - the implementation of local development strategies to improve the administrative governance at rural level (AFIR, 2020). Evaluations after the ending of the first implemented program defined met and partially met indicators, with a positive overall appreciation of the results.

Nevertheless, after the implementation of the NRDP 2007-2013, Romania was still experiencing difficulties in reaching the socio-economic potential of the agricultural sector and rural area. The NRDP 2014-2020 represents an opportunity to address development of the rural area, based on the lessons learned and the progress of the NRDP 2007-2013. Developed around a general objective, the NRDP 2007-2013 referred to creating sustainable use of agricultural and forest land, with the premises for maintaining and conserving the rural natural heritage.

Therefore, NRDP 2014-2020 continues the efforts for rural development by following the strategic objectives correlated with the overall framework of the CAP and the Europe 2020 strategy, as specified in Regulation (EU) no. 1303/2013: (1) restructuring and increasing the viability of agricultural holdings; (2) sustainable management of natural resources and combating climate change; (3) diversification of economic activities, job creation, improvement of infrastructure and services for improving the quality of life in rural areas (European Union, 2013). The objectives of rural development, whose achievement contributes to the Europe 2020 strategy for a sustainable growth, are addressed through six priorities for rural development proposed by the European Union.

View the objectives presented above, this study seeks to develop an understanding of the benefits that European funding (EAFRD, respectively) has on Romania and to describe the country's ability to attract these funds, in the 2014-2020 period. However, because the priorities exposed in the rural development strategy are complex, the objective of this paper is to focus on one of the six priorities, as chosen to be an important issue to discuss upon.

The European strategy proposed a priority concerning the promotion of social inclusion, poverty reduction and economic development in rural areas, focusing on the following aspects: facilitating the diversification, establishment and development of small businesses, as well as job creation; encouraging local development in rural areas. In this way, by following this objective of 
the Union, entrepreneurial initiatives for rural development have been encouraged, and many Romanian SMEs were given the opportunity to be eligible for European funding. The NRDP 2014-2020 allows entrepreneurs to implement their business ideas and sustain the development of the rural communities.

The paper aims to analyze how the European funding influences the development of rural entrepreneurship in Romania. In this respect, the study will comprise an analysis of the existing results of the NRDP 2014-2020, referring to annual evaluation indicators of the project implementation (number of jobs created in supported projects, percentage of rural population targeted by local development strategies, etc.). Ultimately, this paper will contribute with accurate results and discussions concerning the role of EU funds for the rural communities.

Also, the study will describe some of the challenges that Romanian rural entrepreneurship still faces and unresolved issues after implementation of European funding programs. The evaluation studies and annual program implementation reports will be helpful in defining such challenges, notwithstanding the positive outcome resulted at the end of the 2014-2020 period.

\section{Literature review}

\section{Romania's ability to attract European funding}

Among the European Union's objectives, high importance is given to the needs of 22 million farmers and agricultural workers, seeking for a stable and decent standard of living, as well as for a safe food supply market. In this context, the common agricultural policy (CAP) was created for all 28 EU countries, with the aim to provide a sustainable EU agriculture, along with competitiveness in this area, by developing the rural economy and life in rural areas (European Commission, Common agricultural policy, 2013).

Overall, the main objective of the European funds is to provide a sustainable European economy and a favorable environment for creating new job opportunities. In order to implement such funds, partnership agreements are signed by EU and each member state. These agreements specify the way in which the national authorities are to use funding from the European Union. Romania, for example, signed this agreement on 6th of August 2014 (European Commission, 2014).

Once in the European Union, Romania has access to the benefits that CAP brings to EU28 through funding opportunities. Studies regarding the advantages of Romania's accession to the EU say that the most important advantage that Romania should have benefit from is accessing the European funding for rural development (Moldovan, 2015). After the accession, Romania was allocated with significant amounts for promoting economic growth and jobs in rural areas. Between 2007 and 2013, over $€ 8$ billion of EU and national public funds were invested through a rural development program in different activities that support agricultural production, preserve the diversity and enhance cultural wealth and social cohesion of rural areas, as well as improving their economic power.

An ex-post evaluation of NRDP-2007-2013 describes the actual situation of absorption reported to the budget allocated to the National Rural Development Program, indicating a financial execution rate of $89.48 \%$. Respectively, by the end of 2015 , were made payments of around $€ 8.32$ billion ( $€ 7.14$ billion for EAFRD), out of the allocated $€ 9.3$ billion for the national development program (MARD, Ex-post evaluation of NRDP 2007-2013, 2017).

A synthesis of the results after the first NRDP, presented by the European Commission (2013) showed, along with other important results, that the rural development funds had a great impact on 12,700 young farmers that were encouraged to enter the profession, being provided 
with an aid of over $€ 299$ million. Another outcome was the support for the development of Romania's agricultural potential, with an investment of $€ 1.87$ billion for the modernization of more than 2,800 farms. Other investments were directed towards rural infrastructure modernization and access to basic services in around 900 local communities

In the following period, from 2014 to 2020 , as specified in the CAP for Romania, nearly $€ 20$ billion were expected to be invested in Romania's agricultural and rural areas through the CAP. In this direction, priorities such as job creation, economic growth, sustainability, modernization, innovation and quality were defined at European level (European Commission, Common agricultural policy, 2013). The extent of absorption of funds in this period will be described in the results and discussions chapter of this paper.

Nevertheless, researchers claim that Romania has an overall low ability to attract European funds, by comparison with other member states of the European Union. Theoretically, the less developed member states in the European Union should seek to achieve higher EU funds absorption rates, in order to reduce the socio-economic disparities between them and the more developed member states. In the contrary, results show that the reality is different and the regional gaps will increase on medium and long term (Ionescu, 2019).

\section{Rural Romania in the EU funding context}

In the European Union, the development of rural areas is significantly needed, and the solution is to take advantage of new opportunities, by using European funds to develop new business models and enhance new entrepreneurial initiatives. The European rural policies have strategic objectives and sustain development programs, with the aim to create social and economic value in the rural communities (Mauro, 2016). These communities should be empowered to use local resources, to develop business models in order to embrace an entrepreneurial spirit that leads to a rural economic growth, through economic activities and ideas financed by the European Union funds (Răzvanță, 2019).

Challenges such as lack of infrastructure, weak entrepreneurial spirit, and economic instability for young farmers can be overcome only by putting national and European forces together, having a common purpose to sustain rural development, in order to decrease discrepancies between member states. European Union sustains initiatives from member states and provides funding for their needs. Statistically, the most used funds are those referring to agricultural and rural development sector (Ignat et al., 2014).

In the European Union, rural areas and agriculture are notably valued, and their development is of great importance in the EU's objectives. Seeing it from figures, agriculture represents more than $47 \%$ of EU region's total area of land usage (Fehera et al., 2017). To define what rural area means, the European Union uses an urban-rural typology (as expressed in Figure 1), that classifies regions according to NUTS 3 (Nomenclature of Territorial Units for Statistics).

NUTS 3 regions are classified taking into account the share of population living in rural areas, as follows: predominantly rural, intermediate, predominantly urban. At the EU level, $44 \%$ of the EU territory represents the rural regions, $44 \%$ intermediate regions, while urban regions cover only $12 \%$ of the territory (Eurostat, 2018). 


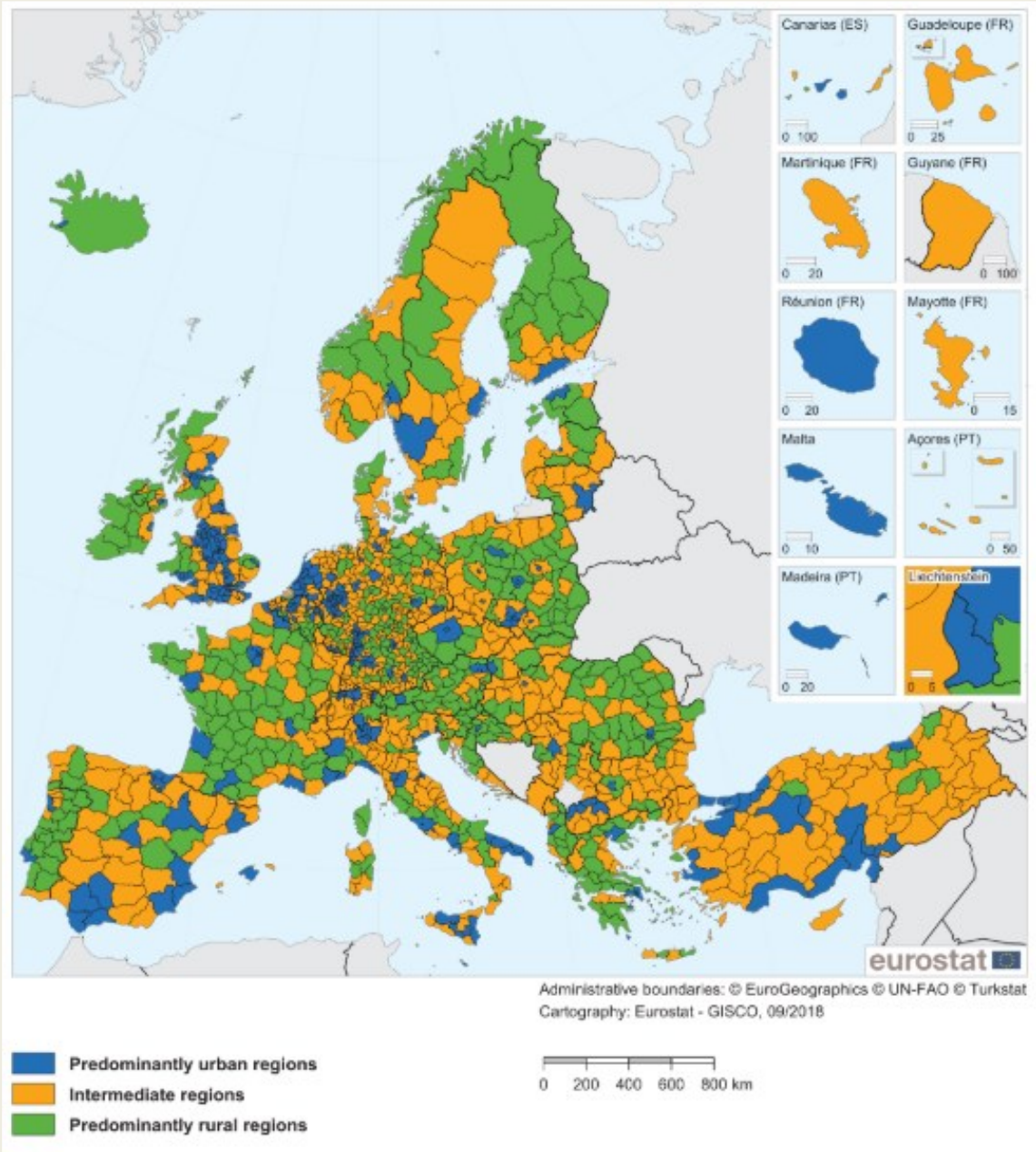

PICBE | 138

Figure 1: EU urban-rural typology according to NUTS 3 (2016)

Source: (Eurostat, 2018).

Figure 2 graphically represents the same classification applied to Romania, with the following estimates: $1.8 \%$ predominantly urban, $21.8 \%$ intermediate, and $76.4 \%$ predominantly rural. More detailed, Romania accounts 42 counties, including Bucharest (according NUTS 3), eight regions (NUTS 2), 320 towns and cities - urban area, and 2861 communes - rural area (NUTS 5). 


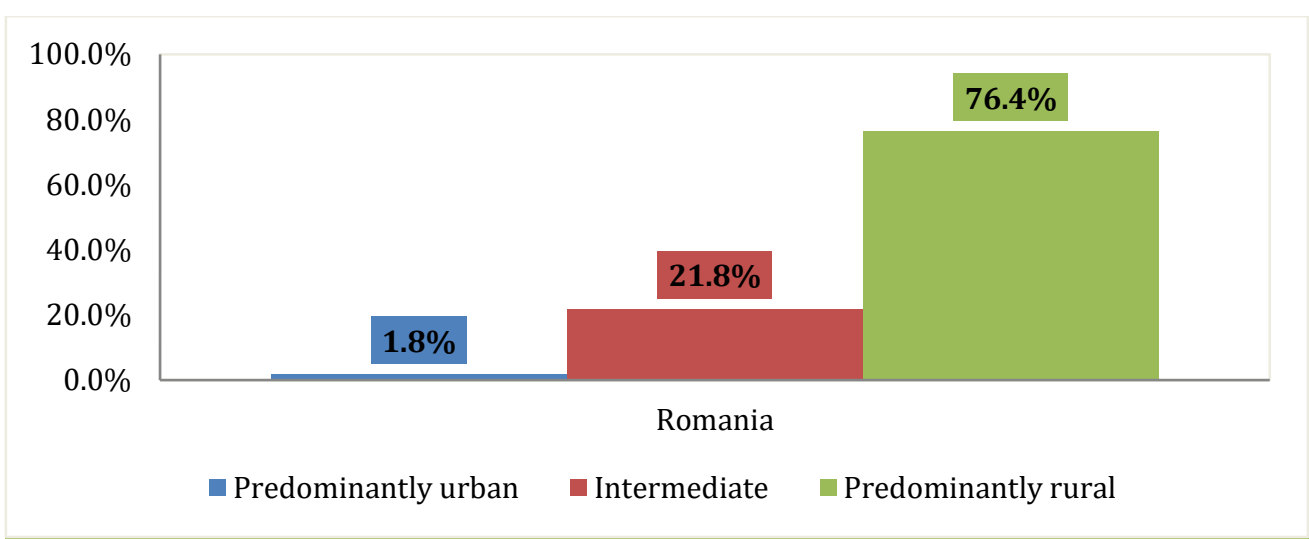

PICBE $\mid 139$

Figure 2: Romania's urban-rural typology according to NUTS 3 (2016)

Source: Author's calculation based on (Eurostat, 2018).

According to (INS, 2019), the latest statistical data show that in 2018, 43.6\% out of the Romanian population have their domicile in rural areas, and $56.4 \%$ in urban areas. These percentages show that there is a significant share of the Romanian population that will benefit from development programs in these areas, and entrepreneurial initiatives could have a great impact on the rural communities.

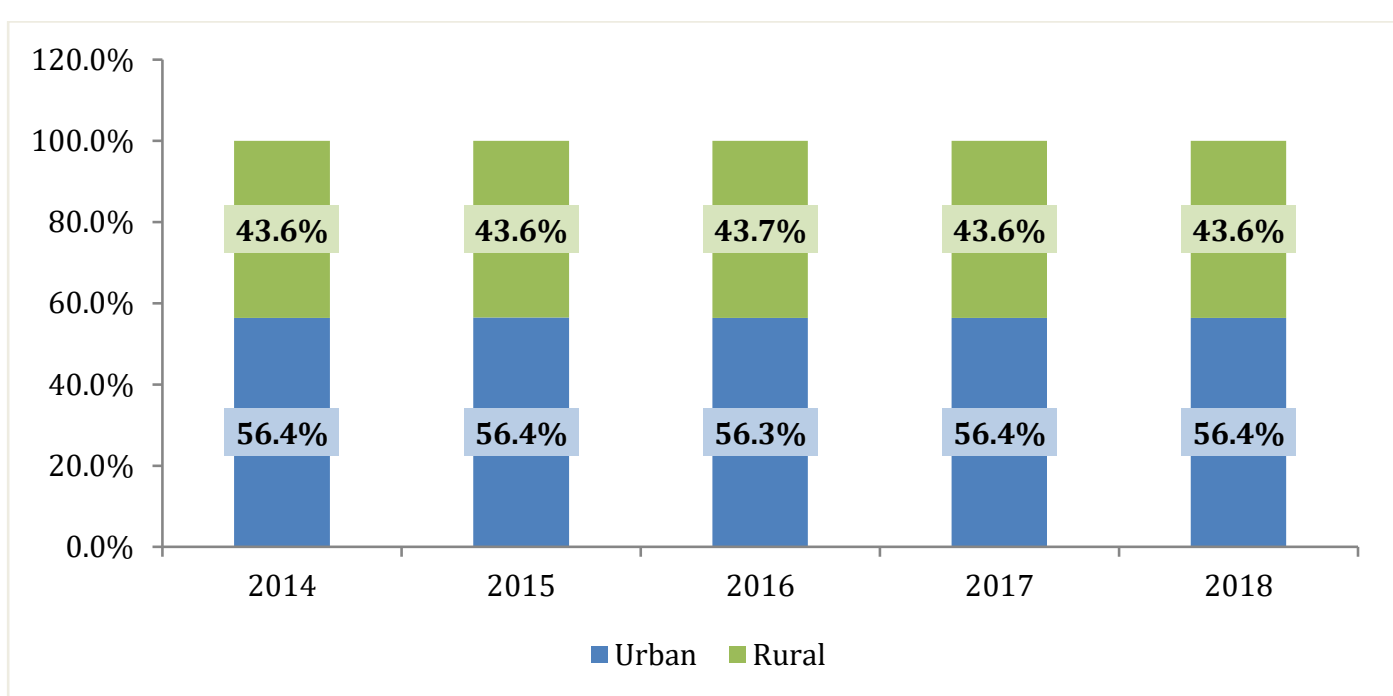

Figure 3: Population by domicile in urban-rural areas on July 1, 2018 - provisional data

Source: Author's calculation based on (INS, 2019).

There are various studies that have researched on the importance of rural areas in the European and national economy. Unfortunately, scenarios don't look very bright, if comparing the development of the Romanian agricultural and rural sector with EU28. Public policies, constraints and lack of national support for these sectors keep Romania in a low position in the European competitive environment. There are significant discrepancies in the economic results for growth and the country has to have well defined long-term actions in order to overcome its position today (Ciutacu et al., 2015).

\section{Methodology}

DOI: $10.2478 /$ picbe-2020-0014,pp. 134-148, ISSN 2558-9652| Proceedings of the $14^{\text {th }}$ International Conference on Business Excellence 2020 
In order to have an image on the role of European funding on rural entrepreneurship, this study focuses on analyzing the existing results of the NRDP 2014-2020, and interpretation of the latest statistical data from trusted sources, referring to annual evaluation indicators of the project implementation (number of jobs created in supported projects, percentage of rural population targeted by local development strategies, etc.).

Literature review is also used to define the context of European funding and the

PICBE $\mid 140$ Romania's ability to attract these funds. In this respect, the most relevant and appropriate studies were identified and used in the theoretical part of the study. Moreover, this study comprises references concerning the on-going evaluation of the rural development program designed by using a combined methodological approach, based on administrative data collection and analysis, qualitative methods for indicator analysis, as well as surveys, interviews and focus groups.

\section{Results and discussions}

As previously mentioned, the objectives of the rural development program are achieved through the six priorities for rural development proposed by the European Union. According to Regulation (EU) no. 1305/2013 of the European Parliament and of the Council, there are some interactions between priorities, intervention domains and measures developed for NRDP 20142020.

In the research context regarding the role of European funds in developing and sustaining rural entrepreneurship in Romania, priority 6 was taken under analysis, in order to define outcomes of the NRDP 2014-2020 and the results on rural entrepreneurship. Table 1 presents this priority, with the respective intervention domains and measures related to this subject matter.

Table 1: Priorities, intervention domains and measures for NRDP 2014-2020

\begin{tabular}{|l|l|l|}
\hline Priority 6 & Intervention Domains (ID) & Measures \\
\hline $\begin{array}{l}\text { The promotion of } \\
\text { social inclusion, } \\
\text { poverty reduction and } \\
\text { economic } \\
\text { development in rural } \\
\text { areas. }\end{array}$ & $\begin{array}{l}\text { (6A) facilitating the diversification, } \\
\text { establishment and development of small } \\
\text { businesses, as well as job creation; }\end{array}$ & $\begin{array}{l}\text { Measure 6 - } \\
\text { Development of farms } \\
\text { and enterprises }\end{array}$ \\
\hline
\end{tabular}

Source: Authors' own research based on Regulation (EU) no. 1305/2013 in (European Union, 2013).

Concerning the implemented measure with respect to this priority, the objective defining Measure 6 is the development of farms and enterprises, through five sub-measures. Beneficiaries were identified for each of the sub-measure, in order to support the objectives and issue proposed in the NRDP 2014-2020. Table 2 presents the main beneficiaries, with the financial support provided for each sub-measure per beneficiary.

Table 2: Beneficiaries of the NRDP 2014-2020 (Measure 6)

\begin{tabular}{|l|l|l|}
\hline Sub-measures & Beneficiaries & Financial support \\
\hline $\begin{array}{l}\text { Sub-measure 6.1 - Support for } \\
\text { the installation of young } \\
\text { farmers }\end{array}$ & $\begin{array}{l}\text {-Young farmer as the sole owner of the } \\
\text { agricultural holding; } \\
\text {-Legal entity with several shareholders where a } \\
\text { young farmer has management and decisional }\end{array}$ & $\begin{array}{l}\text { Non-refundable financial } \\
\text { support of up to } € 50,000 .\end{array}$ \\
\hline
\end{tabular}




\begin{tabular}{|c|c|c|}
\hline & $\begin{array}{l}\text { control, and holds at least } 50 \%+1 \text { of the } \\
\text { shares }\end{array}$ & \\
\hline $\begin{array}{l}\text { Sub-measure } 6.2 \text { - Support for } \\
\text { setting up non-agricultural } \\
\text { activities in rural areas }\end{array}$ & $\begin{array}{l}\text {-Farmers or members of an agricultural } \\
\text { household, who diversify their activity by } \\
\text { setting up a non-agricultural activity in the } \\
\text { rural area for the first time. } \\
\text {-Existing micro and small enterprises in the } \\
\text { rural area, which propose non-agricultural } \\
\text { activities, which they have not carried out until } \\
\text { the date of application for support; }\end{array}$ & $\begin{array}{l}\text { Non-refundable financial } \\
\text { support worth: } \\
\text { - €70,000/ project for } \\
\text { production, medical, } \\
\text { sanitary-veterinary and } \\
\text { agro-tourism activities; } \\
\text { - } 550,000 / \text { project for } \\
\text { other activities. }\end{array}$ \\
\hline $\begin{array}{l}\text { Sub-measure } 6.3 \text { - Support for } \\
\text { the development of small farms }\end{array}$ & $\begin{array}{l}\text { - Farmers who have ownership and / or right of } \\
\text { use for a farm into the category of small farm } \\
\text { according to the relevant definition except for } \\
\text { unauthorized natural persons. }\end{array}$ & $\begin{array}{l}\text { Non-refundable financial } \\
\text { support of } € 15,000 .\end{array}$ \\
\hline $\begin{array}{l}\text { Sub-measure } 6.4 \text { - Investments } \\
\text { in the creation and development } \\
\text { of non-agricultural activities }\end{array}$ & $\begin{array}{l}\text { - Non-agricultural micro and small enterprises, } \\
\text { existing and newly established, from the rural } \\
\text { area; } \\
\text { - Farmers or members of agricultural } \\
\text { households who diversify their basic } \\
\text { agricultural activity by developing a non- } \\
\text { agricultural activity in the rural area within the } \\
\text { already existing enterprise that can be included } \\
\text { in micro and small enterprises, except for the } \\
\text { unauthorized individuals. }\end{array}$ & $\begin{array}{l}\text { Non-refundable financial } \\
\text { support of maximum } 90 \% \\
\text { of the project's total cost } \\
\text { (not more than } € 200,000 \\
\text { /beneficiary in } 3 \text { fiscal } \\
\text { years). }\end{array}$ \\
\hline $\begin{array}{l}\text { Sub-measure } 6.5 \text { - Scheme for } \\
\text { small farmers }\end{array}$ & $\begin{array}{l}\text { - Farmers whose farms meet the definition of } \\
\text { small farm under the simplified scheme in } \\
\text { Pillar } 1 \text { and have applied this scheme for at } \\
\text { least one year. }\end{array}$ & $\begin{array}{l}\text { Non-refundable financial } \\
\text { support equivalent with } \\
120 \% \text { of the annual } \\
\text { amount of support } \\
\text { granted to the small } \\
\text { farmers scheme in Pillar } \\
1 .\end{array}$ \\
\hline
\end{tabular}

Source: Authors' own research with data provided by (AFIR, 2020).

As specified several times in this paper, the financial support for national rural development programs is provided from the EAFRD. In the financial planning for NRDP 20142020, the EAFRD allocation for this period is split as shown in Figure 4, with a total allocated amount of more than $8 €$ billion.

The allocation of EAFRD funds is split also on measures, based on the strategic plan for NRDP 2014-2020. The latest statistical data provided by MARD state that there has been allocated an amount of $878 €$ million for measure 6 , with an absorption rate of $76 \%$, data recorded at the beginning of January 2020 (Table 3). 


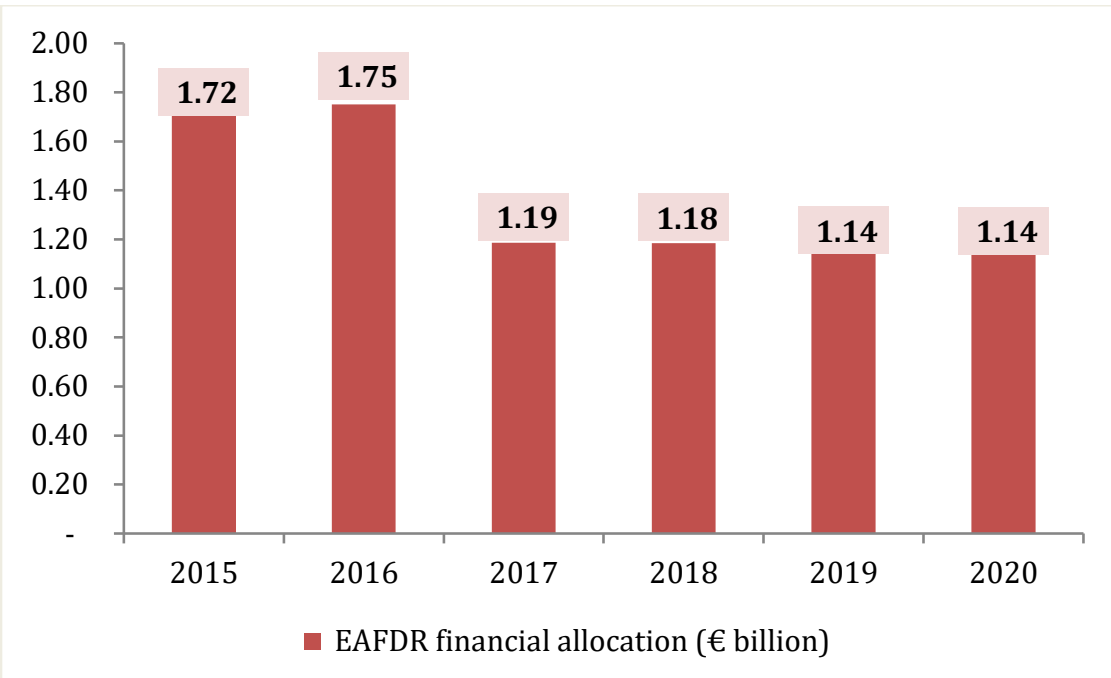

PICBE $\mid 142$

Figure 4: EAFRD allocation according to NRDP 2014-2020 financial plan ( $€$ billion)

Source: Authors' own research with data provided by (MARD, 2019).

Table 3: EAFRD allocation and absorption for NRDP 2014-2020 (Measure 6)

\begin{tabular}{|l|c|c|c|c|c|}
\hline Measure & $\begin{array}{c}\text { EAFRD Budget } \\
\mathbf{2 0 1 4 - 2 0 2 0}\end{array}$ & $\begin{array}{c}\text { Payment } \\
\text { requests }\end{array}$ & $\begin{array}{c}\text { Authorized } \\
\text { amounts }\end{array}$ & $\begin{array}{c}\text { EAFRD } \\
\text { spending (€) }\end{array}$ & $\begin{array}{c}\text { EAFRD } \\
\text { absorption } \\
\text { rate }\end{array}$ \\
\hline Measure 6 & $878,690,544$ & $761,895,037$ & $749,221,031$ & $667,152,007$ & $76 \%$ \\
\hline
\end{tabular}

Source: Authors' own research with data provided by MARD at $16^{\text {th }}$ of January 2020.

This allocation of financial resources encouraged rural entrepreneurs to participate in developing new business ideas for rural development. Rural areas play an important socioeconomic role in Romania because they account a notable share of the total area of Romania, being inhabited by almost half of the population.

Measure 6, through the sub-measures aimed at developing non-agricultural activities in rural areas, support these areas and allow them to benefit from a good business development that would lead to poverty reduction.

The investment towards creation and development of micro and small businesses in nonagricultural areas will create new jobs in rural areas and will lead to the absorption of surplus labor in the agricultural sector. Stimulation of production activities, agro-tourism, and sanitaryveterinary and medical services will increase the degree of attractiveness of rural areas, thus reducing the tendency of residents to migrate to the urban environment in search of new socioeconomic opportunities.

In this context, sub-measures 6.2 and 6.4 were analyzed in order to have an image over the outcomes in the non-agricultural activities supported by NRDP 2014-2020.

Sub-measure 6.2 - Support for setting up non-agricultural activities in rural areas 
The support granted by sub-measure 6.2 contributes to promoting the diversification of agricultural activities through the creation of new non-agricultural activities, at the establishment and development of micro and small enterprises and implicitly, at job creation.

The outcome consists in alternative incomes for the rural population and reducing dependence on the agricultural sector, which contributes to sustainable economic development and poverty reduction in rural areas.

PICBE $\mid 143$

Sub-measure 6.2 aims in particular to create new non-agricultural activities for farmers with agricultural holdings, small farms or members of their families and in general, for rural entrepreneurs in the category of micro or small enterprises. The measure's objective is to participate to the diversification of the rural economy by increasing the number of micro and small enterprises in the non-agricultural sector, the development of services and the creation of jobs in rural areas, as well as encouraging the maintenance and development of traditional craft activities.

Within the 2014-2020 development program, 1924 projects were financed under this submeasure, with an eligible value of $113.80 €$ million. As for the type of activity, $56 \%$ out of the total number of projects were developed in services providers sector, followed by agro-tourism activities with $26 \%$ (see Table 4). In total, 2199 new jobs were created under this sub-measure.

Table 4: Number of projects for sub-measure 6.2 by type of activity

\begin{tabular}{|l|c|c|c|c|c|c|}
\hline \multirow{2}{*}{ Type of activity } & \multicolumn{2}{|c|}{ Number of projects } & \multicolumn{2}{c|}{ Jobs created } & \multicolumn{2}{c|}{ Granted value (€ mil.) } \\
\cline { 2 - 7 } & No. & $\%$ & No. & $\%$ & Amount & \% \\
\hline Services providers & 1076 & $56 \%$ & 1213 & $55 \%$ & 54.64 & $48 \%$ \\
\hline Craft activities & 119 & $6 \%$ & 125 & $6 \%$ & 8.33 & $7 \%$ \\
\hline Agro-tourism activities & 500 & $26 \%$ & 427 & $19 \%$ & 34.82 & $31 \%$ \\
\hline $\begin{array}{l}\text { Production and marketing of } \\
\text { non-agricultural products }\end{array}$ & 229 & $12 \%$ & 434 & $20 \%$ & 16.01 & $14 \%$ \\
\hline Total & $\mathbf{1 9 2 4}$ & $\mathbf{8 0 0 \%}$ & $\mathbf{2 1 9 9}$ & $\mathbf{1 0 0 \%}$ & $\mathbf{1 1 3 . 7 9}$ & $\mathbf{1 0 0 \%}$ \\
\hline
\end{tabular}

While valuing the projects implemented in the rural area, a classification of areas was defined. Under this classification, Figure 5 shows us how the projects were implemented, as follows: $53 \%$ of projects were implemented in normal areas, $22 \%$ in mountain area, $20 \%$ in areas of significant constraints (for example, areas with natural constraints such as drought), and only $5 \%$ in areas with specific constraints (Danube Delta).

Within this sub-measure, several types of beneficiaries had the opportunity to benefit from the funding put at their disposal. In this respect, rural entrepreneurship was developed through the creation of new micro enterprises (36\%), representing the majority of projects implemented in the rural areas, in the non-agricultural sector, followed by farmers that developed as well non-agricultural activities $(29 \%)$.

From the total number of jobs created, the new micro enterprises provided $44 \%$ of the new jobs, respectively 959 (see Figure 6). 


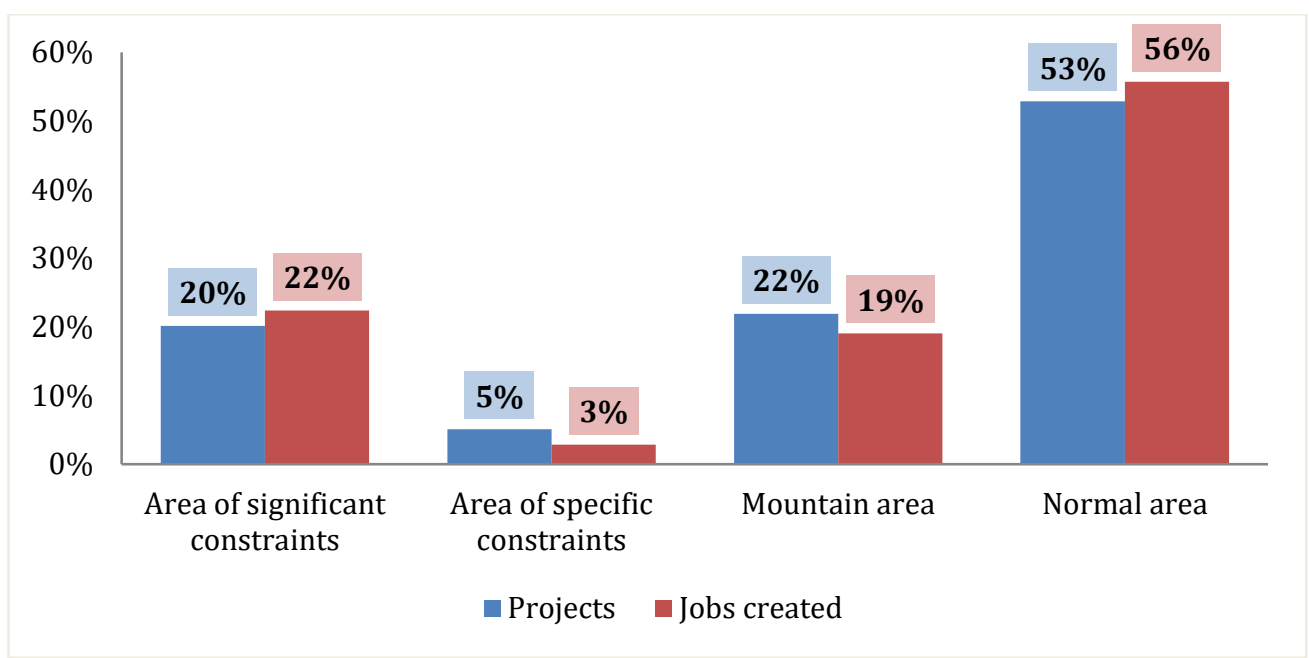

PICBE $\mid 144$

Figure 5: Projects and jobs created for sub-measure 6.2 by area

Source: Authors' own research with data provided by MARD.

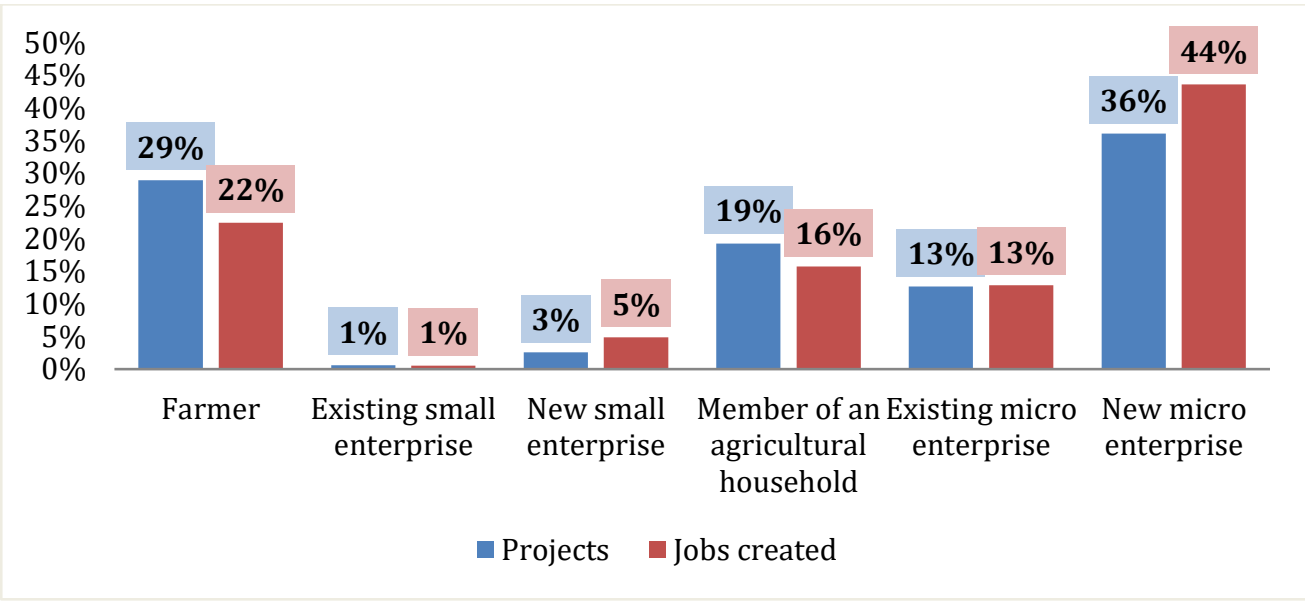

Figure 6: Projects and jobs created for sub-measure 6.2 by beneficiary type

Source: Authors' own research with data provided by MARD.

\section{Sub-measure 6.4 - Investments in the creation and development of non-agricultural activities}

In the same context of developing rural entrepreneurship, sub-measure 6.4 contributes to stimulating the business environment in the rural area. It supports increasing the number of nonagricultural activities carried out in rural areas, development of existing non-agricultural activities, job creation. Consequently, it will lead to increasing the incomes of the rural population, reducing the differences between rural and urban areas, as well as diversification of the economic activities of farmers or members of agricultural households by practicing non agricultural activities in order to increase the incomes and the creation of occupational alternatives.

In the NRDP 2014-2020, under sub-measure 6.4 were financed 916 projects, with an eligible value of $177.38 €$ million. Splitting projects by type of activity, $45 \%$ out of the total 
number of projects were related to investments in infrastructure in the tourist reception units within agro-tourism activities. The second most used type of activity, almost as much as the infrastructure, is the services sector, with a total share of $41 \%$ (see Table 5). Through these projects, 1587 new jobs were created and 3934 jobs were maintained.

Table 5: Number of projects for sub-measure 6.4 by type of activity

PICBE | 145

\begin{tabular}{|l|c|c|c|c|c|c|}
\hline \multirow{2}{*}{ Type of activity } & \multicolumn{2}{|c|}{ Number of projects } & \multicolumn{2}{c|}{ Jobs created } & \multicolumn{2}{c|}{ Granted value (€ mil.) } \\
\cline { 2 - 7 } & No. & $\mathbf{\%}$ & No. & $\mathbf{\%}$ & Amount & $\%$ \\
\hline Services & 375 & $41 \%$ & 731 & $46 \%$ & 66.14 & $37 \%$ \\
\hline Craft activities & 19 & $2 \%$ & 51 & $3 \%$ & 3.13 & $2 \%$ \\
\hline $\begin{array}{l}\text { Infrastructure in the tourist reception } \\
\text { units }\end{array}$ & 415 & $45 \%$ & 527 & $33 \%$ & 88.32 & $50 \%$ \\
\hline $\begin{array}{l}\text { Production and marketing of non- } \\
\text { agricultural products }\end{array}$ & 87 & $9 \%$ & 235 & $15 \%$ & 15.52 & $9 \%$ \\
\hline $\begin{array}{l}\text { Production and marketing of biomass } \\
\text { fuel }\end{array}$ & 20 & $2 \%$ & 43 & $3 \%$ & 4.27 & $2 \%$ \\
\hline Total & $\mathbf{9 1 6}$ & $\mathbf{1 0 0 \%}$ & $\mathbf{1 5 8 7}$ & $\mathbf{1 0 0 \%}$ & $\mathbf{1 7 7 . 3 8}$ & $\mathbf{1 0 0 \%}$ \\
\hline
\end{tabular}

Source: Authors' own research with data provided by MARD.

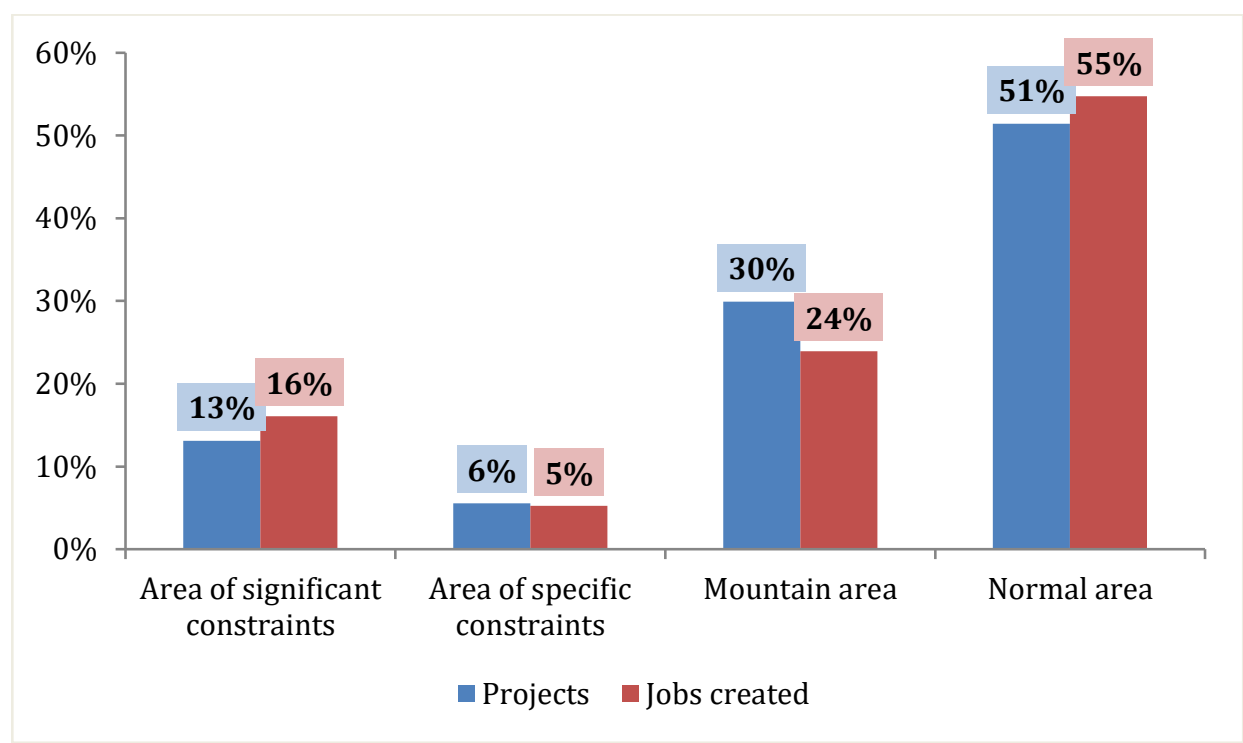

Figure 7: Projects and jobs created for sub-measure 6.4 by area

Source: Authors' own research with data provided by MARD.

Figure 7 represents the split of the number of projects implemented by area, for this submeasure: $51 \%$ of projects were implemented in normal areas, $30 \%$ in mountain area, $13 \%$ in areas of significant constraints, and only $6 \%$ in areas with specific constraints. 


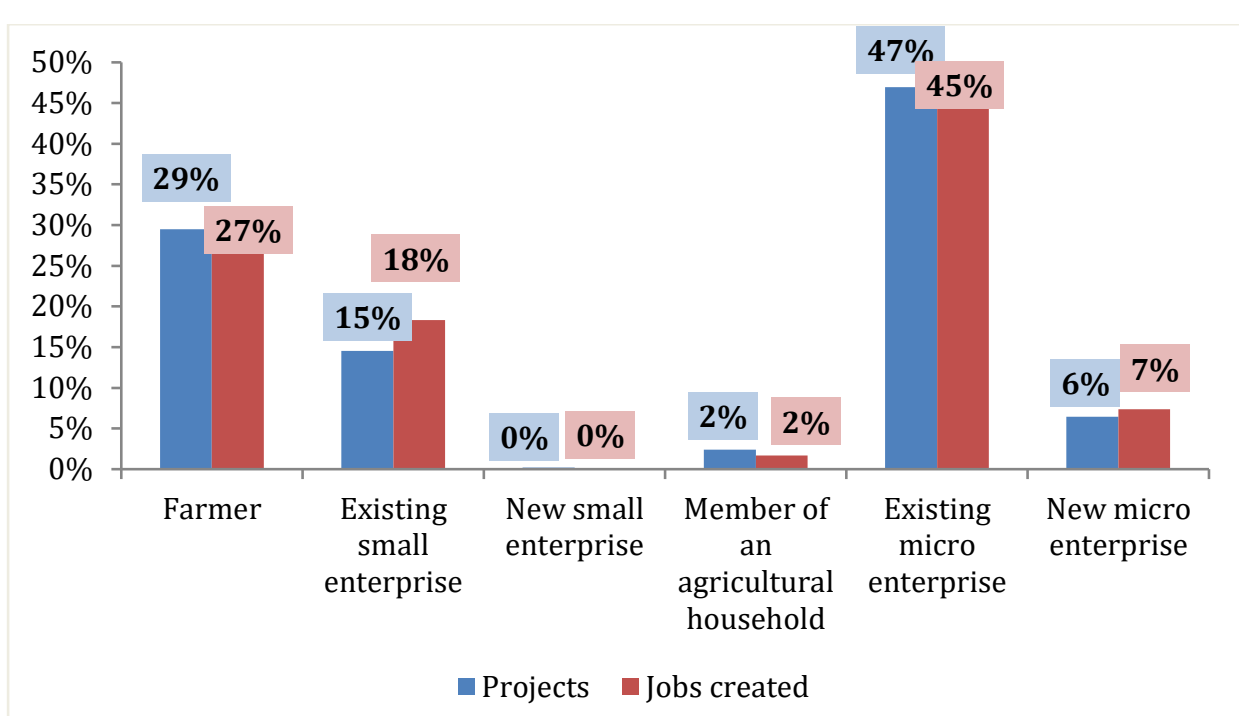

PICBE | 146

Figure 8: Projects and jobs created for sub-measure 6.4 by beneficiary type

Source: Authors' own research with data provided by MARD

As regards the type of beneficiaries, different from the projects under sub-measure 6.2, the projects developed here were focused on existing micro enterprises $(47 \%)$ rather than on creating new micro enterprises (only 6\%), as represented in Figure 8 . This can be explained by the purpose of this sub-measure, that of supporting investments in improving infrastructure in non-agricultural businesses.

\section{Conclusions}

According to the latest results of the evaluation study from 2019 on the progress of NRDP 20142020, the projects implemented within the rural development program have positively contributed to the achievement of the objectives among Priority 6, considering the results until this stage.

Referring to some specific indicators for this evaluation, we can draw some conclusions regarding the extent in which projects within NRDP have influenced the development of rural entrepreneurship. Entrepreneurial initiatives supported the diversification, creation and development of enterprises and the creation of jobs (however to a lesser extent in comparison with the 2023 target - 24,474 new jobs). Overall, all beneficiaries of measure 6 contributed to increasing the number of jobs compared to the situation prior to the intervention (for example, more than $80 \%$ of the beneficiaries in sub-measure 6.2 created, in most cases, about 2 new jobs).

Diversification of the rural economy is another recorded outcome, from the perspective of encouraging the creation of micro and small enterprises in different domains. Within sub-measure 6.2 , the contribution of NRDP provided added value for segments such as handcraft, marketing and production activities, and the introduction of new services and production processes.

The support for local development in rural areas aimed at involving inhabitants and workers in the implementation and development of local strategies, considering their specific needs. These projects were mostly conducted by SMEs $(51 \%)$, public institutions (35\%), other types of local organizations (11\%) and NGOs (3\%), representatives of different needs and interests. 
Nevertheless, the results of NRDP 2014-2020 show that there are still problems in reaching targets and becoming more competitive in the European funding context. The limitations of this paper refer to the lack of defining more specifically the challenges that Romania still faces after the implementation of the present NRDP. In a further research, recommendations would be to describe specific cases of rural development projects and impact on the rural communities.

\section{References}

AFIR. (2020). Rural Development - EAFRD. Retrieved from Agency for Rural Investment Financing: https://www.afir.info

Ciutacu, C., Chivu, L., \& Andrei, J. V. (2015). Similarities and dissimilarities between the EU agricultural and rural development model and Romanian agriculture. Challenges and perspectives. Land Use Policy, 44, 169-176.

European Commission. (2013). Common agricultural policy. Retrieved from The official website of the European Union: https://ec.europa.eu/info/sites/info/files/food-farmingfisheries/by_country/documents/cap-in-your-country-ro_ro_0.pdf

European Commission. (2013). Common agricultural policy. ${ }^{-}$Retrieved from The official website of the European Union: https://ec.europa.eu/info/food-farming-fisheries/keypolicies/common-agricultural-policy_en

European Commission. (2014). Partnership Agreement Romania 2014RO16M8PA001.1.2. Retrieved from https://www.fonduri-ue.ro/acord-parteneriat\#varianta-în-engleză

European Council. (2005). Council Regulation (EC) no. 1290/2005. Official Journal of the European Union, 48(L 209), 1-25.

European Council. (2005). Council Regulation (EC) no. 1698/2005. Official Journal of the European Union, 48(L 277), 1-41.

European Union. (2013). Regulation (EU) no. 1305/2013 of the European Parliament and of the Council. Official Journal of the European Union, 56(L 347), 487-548.

European Union. (2020). Countries. Retrieved from The official website of the European Union: https://europa.eu/european-union/about-eu/countries_en

Eurostat. (2018). Rural areas and the primary sector in the EU. Retrieved from https://ec.europa.eu/info/sites/info/files/food-farming-fisheries/farming/documents/eurural-areas-primary-sector_en.pdf

Fehera, A., Goșa, V., Raicov, M., Haranguș, D., \& Condeac, B. V. (2017). Convergence of Romanian and Europe Union agriculture - evolution and prospective assessment. Land Use Policy, 67, 670-678.

Ignat, R., Stoian, M., \& Roșca, V. (2014). Socio-economic aspects of rural Romania. Procedia Economics and Finance, 1331 - 1338.

INS. (2019). Romania in cifre - breviar statistic. Retrieved from National Institute of Statistics: $\mathrm{http} / / / \mathrm{www}$. insse.ro/cms/sites/default/files/field/publicatii/romania_in_cifre_2019_2.pdf

Ionescu, R.-V. (2019). Romania vs. Opportunity of using European Strütural and Investment Funds.

Istudor, N. (2006). Dezvoltarea rurala si regionala a Romaniei in perspectiva integrarii in Uniunea Europeana. Bucharest: ASE Publishing.

MADR. (2019). National Rural Development Program 2014-2020 9th version. Retrieved from Ministry of Agriculture and Rural Development: https://www.madr.ro/pndr-20142020/implementare-pndr-2014-2020/documente-aprobate.html

MARD. (2017). Ex-post evaluation of NRDP 2007-2013. Retrieved from Ministry of Agriculture and Rural Development: https:/www.madr.ro/docs/dezvoltare-rurala/studii/Ex-postevaluation-of-NRDP-2007-2013-EN.pdf

MARD. (2019). National Rural Development Program 2014-2020 9th version. Retrieved from Ministry of Agriculture and Rural Development: https://www.madr.ro/pndr-20142020/implementare-pndr-2014-2020/documente-aprobate.html 
Mauro, R. (2016). Sustaining social and rural entrepreneurship towards hybrids. Responsible entrepreneurship: vision, development and ethics, 64-74.

Moldovan, I. (2015). Considerations on the Advantages and Disadvantages of Romania's Accession to the European Union. Procedia Economics and Finance, (pp. 600-606).

Răzvanţă, F. (2019). Conceptual framework for rural business models. Proceedings of the International Conference on Business Excellence, 13(1), 1130-1139.

PICBE $\mid 148$ 